ISSN 2519-2523 (print)

Chornomors'ka mynuvshyna. - 2020. - No.15

DOI: $10.18524 / 2519-2523.2020 .15 .218688$

УДК 94(477) “2020”

\title{
HISTORIANS AND SCIENTIFIC-PRACTICAL CONFERENCE: MYTH OR REALITY (ON THE EXAMPLE OF SCIENTIFIC-PRACTICAL CONFERENCE "O.M. POL' IN HISTORY AND CITY MEMORY OF DNIPRO, 2020")
}

\author{
Svitlana Kaiuk \\ ORCID: https://orcid.org/0000-0002-2452-2642 \\ PhD (History), Associate Professor \\ Oles Honchar Dnipro National University \\ 72, Gagarina av., Dnipro, 49000, Ukraine \\ skaiuk22@gmail.com
}

The information report is dedicated to the scientific-practical conference held in Dnipro. Reports of the conference participants, the practical component, which is strengthened by the role of local authorities of Dnipro, the ability of historians to influence the formation of historical and cultural landscape of the city, historical memory, the need to change the conference model of behavior at conferences designed for representatives of various sciences and practice are analyzed. The personal responsibility of historians who seek to go beyond academic offices into public space and the possible dangers in the formation of new images of "heroes" are emphasized. The conference is dedicated to the results of the search for the burial place and grave of a prominent man in the history of the Dnipro - Alexander Pol'. Church of St. Lazarus, near which in the late XIX century Pol' was buried, was destroyed by Soviet authorities, the burial place was considered inaccessible for research. The interest of the community, local bloggers, caring historians, financial and organizational support of the mayor of Dnipro allowed to adjust the location of the burial place. Archaeological and anthropological studies have confirmed this. The architects designed a new project of the pantheon of memory, and city officials began to implement a project for a new Sevastopol Park.

Key words: historical memory, public history, scientific-practical conference, O.M. Pol', the image of the city.

\section{Світлана Каюк}

ORCID: https://orcid.org/0000-0002-2452-2642

Кандидат історичних наук, доцент Дніпровський національний університет імені Олеся Гончара

Пр. Гагаріна, 72, Дніпро, 49000, Україна skaiuk22@gmail.com

\section{ІСТОРИКИ ТА НАУКОВО-ПРАКТИЧНА КОНФЕРЕНЦІЯ: МІФ ЧИ РЕАЛЬНІСТТЬ (НА ПРИКЛАДІ НАУКОВО-ПРАКТИЧНОЇ КОНФЕРЕНЦЇ̈ «О. М. ПОЛЬ В ІСТОРЇ̈ ТА МІСЬКІЙ ПАМ'ЯТІ ДНІПРА», 06 ЖОВТНЯ 2020 р., ДНІПРО)}

Інформачійне повідомлення присвячене науково-практичній конференції, щуо відбулася у Дніпрі. Аналізуються доповіді учасників конференції, практична складова, яка посилена роллю місиевої влади Дніпра, можливості істориків впливати на формування історикокультурного ландшафту міста, історичної пам'яті, необхідність зміни конферениійної 
моделі поведінки на конференціях, які розраховані на участь представників різних галузей науки та практики. Підкреслюється особиста відповідальність істориків, які прагнуть вийти за межі академічних кабінетів у публічний простір та можливі небезпеки при формуванні нових образів «героїв».

Ключові слова: історична пам'ять, публічна історія, науково-практична конференція, О.М. Поль, образ міста.

«Якщо ви думаєте, що пригоди небезпечні, спробуйте рутину - це смертельно...»

(П. Коельо)

Конференція як форма організації наукової діяльності, можливість обговорення досягнень, обмін думками $\epsilon$ необхідною та обов'язковою як ковток повітря компонентою життя для тих, хто вважає себе науковцем. Не існує наукових звітів, в яких не було б відповідної графи, яка обчислює відповідне ККД наукової діяльності через конференції. Різновидів конференцій безліч, як і похідних від неї (семінарів, симпозіумів тощо). Науково-практична конференція - один із таких різновидів, яких в академічному просторі незчисленна кількість. Здавалося б, це один із найбільш зрозумілих видів почесного зібрання, адже воно орієнтоване на значимість практичних результатів. I якщо 3 представниками технічних наук все зрозуміло, результат їхньої наукової діяльності відразу може бути скерований на практику, то 3 гуманітаріями складніше. Результат як уточнення наукової тези мало зрозумілий громадськості. Питання на кшталт «а чи має науковий продукт бути цікавий громадськості» у даному випадку не дискутується (практична складова підкреслена назвою), так само, як і філософські роздуми, про те, чи повинна академічна наука виходити у публічний простір. Відповідь на останнє питання кожен науковець вирішує самостійно і часто безапеляційно вважає свою точку зору єдино вірною. Однак науково-практичний жанр передбачає вихід на більш широку публіку, що відразу наражає на небезпеку. Публічну складову бажано підсилити висвітленням у 3MI, отже виникає небезпека викривлення інформації. Для журналістів та публіки певні неточності мало зрозумілі, професіоналів відразу скорчить, а колеги по цеху із задоволенням накинуться 3 критикою. Широкий резонанс тут же активізує увагу шанувальників справи, краєзнавців, істориків за освітою (на лихо, підсиленою дипломами кандидатів, а то й докторів наук) та за покликом душі, які «ну точно все знають» і коригувати свої знання не збираються. Їхня думка у публічному просторі часто може навіть переважати, бо за правилом, це не ледачі люди з відповідною «активною життєвою позицією». Отже, виникає наступне питання: а чи варто витрачати на це зусилля? Відповідь має бути підсилена назвою конференції, адже $є$ необхідність колегіально підтвердити практичний результат та зафіксувати це резолюцією.

У жовтні 2020 р. у Дніпрі відбулася саме така науково-практична конференція, яка ідеально відповідає жанру. I навіть участь академічної спільноти справу не зіпсувала. Олександр Миколайович Поль - знакова постать міста та регіону. Подібні імена (хоча для дніпрян він $є$ виключним і майже геніальним, «степовим Колумбом», який «відкрив Каліфорнію») «героїв», які зробили місто, край таким, яким він $\epsilon$, можна бачити і в інших місцях. Їх можна віднести до категорії відомих. Але ідеологічні, а слідом за ними й історіографічні хитання забезпечують тривале забуття, потім поступове пригадування, яке може вийти за межі академічного простору на вулиці міста, а може лишитися зрозумілим та очевидним для «обраних» (у даному випадку істориків). Суспільна впізнаваність «героя» залежить або від наполегливості та небайдужості істориків (і в даному випадку шанувальники та фахівці за покликом 
душі можуть значно допомогти, варто лише скоординувати та зорганізувати їхні зусилля), або від дій місцевої влади та чиновників. Останнє в українських реаліях та умовах постійної кризи (економічної, фінансової і не тільки...) є для гуманітаріїв мрією умовно не здійсненою. Однак у Дніпрі такі «марева» (особливо для тих істориків, які дослідженню О.М. Поля та його епохи присвятили значну частину наукового життя) виявилися неочікувано реальними.

Конференція підвела підсумок тривалої наукової діяльності істориків кількох поколінь (Г. Швидько, В. Лазебник, І. Кочергин, В. Старостін, М. Кавун, Т. Портнова - більшість виступила 3 доповідями) та поєднала їх із зусиллями влади у меморіалізації імені О. М. Поля. Роль постаті О. М. Поля у визначенні пріоритетів діяльності мера міста Б. А. Філатова та його оточення, бізнесового олімпу, керівників різного рівня та структур ще доведеться з'ясувати. Очевидно лише, що такому неочікуваному розмаху сприяла не тільки реформа децентралізації з усіма наслідками, але й рідкісний збіг: Б. А. Філатов - історик за освітою, кандидат юридичних наук, журналіст, бізнесмен та практик, який звик доводити справи (навіть дуже ризиковані) до кінця. Витрачати чималі гроші на гуманітарні проекти під час війни, пандемії, знов кризи, виборчих перегонів - випробування не 3 легких. Значної кількості голосів зазвичай такі проекти не додають. Але в даному випадку, сподіваємося, вийшло і це.

Заручившись підтримкою наукової громадськості міста, конференція передусім мала підсумувати результат практичної діяльності людей з абсолютно різних галузей. Черговий спалах зацікавленості постаттю О.М. Поля спровокував місцевий блогер, молодий шанувальник історії рідного міста А. М. Костюк (його виступ на конференції викликав значний інтерес), який навесні 2019 р. віднайшов у інтернет-мережі новий, раніше невідомий аерофотознімок Люфтваффе червня 1944 р., звернувся до міської влади 3 проханням купити його, синхронізував із сучасною картою міста та зрозумів, що він може значно скоригувати «беззаперечно» відомі історикам факти. Передусім мова йшла про розташування Лазаревської церкви, біля якої свого часу був похований почесний громадянин міста О. М. Поль, але яку рішенням радянської влади було підірвано у 1950ті pp., а всі поховання знесені. На місці цвинтаря за радянськими канонами було побудовано Севастопольський парк із: розважальним майданчиком для дітей, пивбаром, танцювальним майданчиком та естрадою. На «переконливу» думку місцевих істориків та краєзнавців залишки церкви стали основою насипу курганного типу, на якому тоді ж було збудовано меморіал на честь незрозумілих «перемог» Росії у Кримській війні та вшанування пам'яті загиблих (поруч знаходиться відома лікарня ім. I. Мечникова, яка під час війни дійсно лікувала поранених, а померлих ховали на Севастопольському цвинтарі). Меморіал занесено до реєстру пам'яток - отже чіпати не можна. Відтак могила О. М. Поля, яка розташовувалася біля церкви, вважалася втраченою назавжди. Комп'ютерна синхронізація, виконана А.М. Костюком, переконливо доводила інше: Лазаревська церква знаходилася на кілька десятків метрів правіше від кургану, отже археологічні дослідження можливі. Наполегливість блогера та здатність влади на неформальні рішення (які інколи можуть здатися божевільними) змусили діяти.

Археологічні дослідження - необхідна складова діяльності тих керівників господарських об'єктів, які займаються будівництвом. Це зрозуміла річ. Малозрозумілим для громадськості, та й деяких фахових істориків, $є$ фінансування археологічних розкопок за рахунок місцевого бюджету. У Дніпрі вже кілька років працює власна Дніпровська археологічна експедиція, яку очолює кандидат історичних наук, доцент, старший науковий співробітник ДП «НДЦ «Охоронна археологічна служба України» Інституту археології НАН України Д. Л. Тесленко. 
Замовником та організатором археологічних досліджень, а також координатором зусиль щодо популяризації відповідної діяльності у ЗМІ, піар-кампанії на честь О. М. Поля (із амбітною метою, яка, маємо надію, змінить сірий радянський історикокультурний ландшафт міста та призведе до створення нового його образу в очах містян) стало комунальне підприємство міської ради «Етнографічні парки Дніпра» в особі директора Д. Г. Каюка (кандидат історичних наук, доцент). Отже, від самого початку було скоординовано зусилля громадських активістів, влади, чиновників, які вміють реалізовувати конкретні проекти та істориків. Д. Г. Каюк повідомив на конференції про всі ті випробування, передусім організаційного, бюрократичного характеру, що випали на долю дослідників під час пошуків руїн церкви та могили О. М. Поля й заходи, які вживалися для ідентифікації знайдених людських останків. Д. Л. Тесленко у своїй доповіді закцентував увагу на археологічних дослідженнях Лазаревського церковно-меморіального комплексу, проведених у Севастопольському парку влітку 2020 р. Технічна (а відтак і практична) переконливість можливості проведення археологічних розкопок на момент їх планування була підсилена доповіддю С. М. Веретюка (керівник Noodohere Engineering School) про результати пошуку фундаменту церкви з допомогою геолокатора.

Найбільший інтерес для представників ЗМІ викликала доповідь О. Д. Козак (кандидат історичних наук, старший науковий співробітник відділу біоархеології Інституту археології НАНУ) «Антропологічна ідентифікація останків 3 поховання кінця XIX ст. зі склепу № 2», яка переконливо довела, що саме ці останки належать О. М. Полю (а не зі склепу № 1, як спочатку вважали археологи). Результати антропологічного аналізу, порівнянням 3 фотодокументами, дослідженнями істориків щодо специфічної діяльності та образу життя О.М. Поля дозволили зробити висновки переконливими.

Практичну складову конференції підсилила участь міського голови м. Дніпра, який вручив подяки всім причетним, починаючи від тих істориків, які досліджували життя та діяльність О. М. Поля ще за часів радянської влади (а це було не те що ризиковано, але не канонічно), розшукали будинок, в якому він проживав і який на диво зберігся (доповідь В.ІІ. Лазебник, завідувачки відділу наукових досліджень історії України та краю Дніпропетровського національного історичного музею ім. Д. І. Яворницького), популяризували його та робили відомими й закінчуючи тими, хто проводив археологічні розкопки й експертизи. До речі, міській владі, попри значні зусилля, ще не вдалося повернути будинок О. М. Поля у власність громади (на сьогодні він $є$ приватною власністю швейцарської компанії «GCONNECT AG»). Міський голова Б. А. Філатов звернувся до фахівців із проханням допомогти у формуванні історичної пам'яті міста, а відтак сприяти зміні його образу в очах як мешканців, так і гостей, журналістів тощо. Практичні висновки відразу мали робити директор департаменту парків та рекреацій Дніпровської міської ради О. В. Буйволюк та директор КП «Дирекція територій і об'єктів рекреацій» О. С. Давиденко, а слідкувати за доцільністю та можливістю майбутніх змін Севастопольського парку згідно з законодавчими нормами щодо природно-охоронної зони Н. Ю. Лиштва (начальник управління з питань культурної спадщини Дніпровської міської ради). А те, що плани щодо переформатування історико-культурного ландшафту м. Дніпро, що якісно прикрасять місто та скоригують історичну пам'ять_широкого кола містян, можуть бути реалізовані на практиці стало зрозумілим після доповіді архітектора, члена НСАУ О. А. Іваницької «Музеєфікація розкопів, артоб'єкти - сучасні рішення благоустрою відповідно до законодавства та кліматичної стратегії міста». В такий 
спосіб учасникам конференції був представлений проект реконструкції Севастопольського парку 3 урахуванням побажань істориків та спрямований на створення нового соціо-культурного ландшафту міста, якісно нових місць відпочинку, які ненав'язливо можуть слугувати основою для побудови нової історичної та публічної культури містян. Майбутній пантеон славетних містян Дніпра може бути не тільки місцем вшанування, але й майданчиком для проведення культурних заходів на відкритому просторі. Доповідь О. I. Бондаренко (старший викладач Придніпровської державної академії будівництва та архітектури) підкреслила давні прагнення архітектурної еліти міста щодо реконструкції Севастопольського парку з відновленням церкви Святого Лазаря.

Таке нестандартне поєднання вузьких фахівців із абсолютно різних галузей з метою вирішення конкретних завдань: засвідчити достовірність віднайдених останків як таких, що дійсно належать О. М. Полю, та максимально широко продумати шляхи та доцільність меморіалізації, створення чи нестворення «образу героя», можливі небезпеки формування колективної пам'яті тощо - змусили професійних істориків дещо змінити модель звичайної поведінки на наукових історичних конференціях. Їхні доповіді мали бути зрозумілі абсолютно всім присутнім, отже слід було значно скоригувати термінологічний апарат та лексику. Присутність колег по цеху змушувала робити це максимально коректно та убезпечувала від примітивізації. Це виявилося можливим та практично необхідним. Історик, який виходить 3 кабінету у межі публічного простору, має тонко відчувати лексичну межу дозволеного (багато синонімів, термінів, так звана «науковість» та химерність недоречні; під час таких зібрань стає зрозумілим, що надмірне використання подібних слів та виразів не підкреслює «розумність» доповідача, а насправді часто приховує відсутність думки як такої). Публічний простір та можливість впливати на суспільні процеси змушує істориків більше думати над тим, до чого не звикли кабінетні фахівці, - відповідальність. Практична реалізація задуманого, тісна координація із представниками ЗМІ (а така була під час усієї кампанії пошуків могили О. М. Поля через істориків-практиків, які не лінувалися готувати матеріали для прес-служби міської ради), а відтак можливість впливати на формування історичної пам'яті, змушують постійно думати про власну відповідальність. Наявність титулованих «весільних генералів» на такій конференції не приймуть, а навіть якщо їхня присутність буде необхідна згідно 3 протоколом, їм доведеться бути максимально короткими у виступах. Отже, справжня науково-практична конференція значно коригує конференційну поведінку науковців.

Відповідальність публічних істориків та необхідність глибокого думання над популяризацією «героїв» підкреслили дискусійні доповіді кандидатки історичних наук, доцентки Дніпровського національного університету ім. Олеся Гончара Т. В. Портнової «ІІторична постать як візитівка міста: сучасний досвід» та кандидата історичних наук, доцента, директора КП «Етнографічні парки Дніпра» Д.Г. Каюка «У пошуках героя: Дніпро й міфологеми О. Поля». Доповідь доктора історичних наук, доцента Дніпровської «Політехніки», начальника відділу Українського інституту національної пам'яті I. С. Кочергіна «Міфотворчість як зворотній бік популярності: Олександр Поль в сучасних дослідженнях» стала відповіддю на пасквільні писання «колег по цеху», без яких за умови такої потужної кампанії, ясна річ, не обійшлося (мова йде про публікації В. Заруби на порталі Historians, які насправді на наукову критику навіть не заслуговують). Знаковість постаті О. М. Поля у контексті проблеми історичної пам'яті підкреслив доктор історичних наук, професор, декан історичного факультету Дніпровського національного університету ім. Олеся Гончара С. І. Світленко. 
Роздуми над теорією та практикою науково-практичних конференцій можна продовжувати до безкінечності, як й інформаційне повідомлення про дану конференцію, що була присвячена О. М. Полю. Очевидно лише, що рівень практичності конференції залежить від іï замовника та організатора, а історики, які будуть доречні для виконання практичних завдань, знайдуться. Практичний результат конференції $\epsilon$ ще й в іншому. На історико-культурницькій мапі України неочікувано з'являється Місто, мешканці якого поступово починають цікавитися своєю історією (і сприймати іiі саме як свою), люблять його та пишаються ним, розповідають Його історії (вигадані та реальні). До сих пір такими були Львів та Одеса, це надавало колориту та приваблювало туристів. Дніпро з'являється неочікувано, але достатньо швидко (підтримка та фінансування міської влади, особиста зацікавленість мера-історика дозволяють сподіватися на тривале співробітництво та практичний результат). В такий спосіб сучасне місто та його очільник (підсвідомо чи ні?) продовжують традиції О. М. Поля - лишати пам'ять про себе! I це не тільки нові вулиці, площі, мости та модерні засоби сполучення, як було за часів залізної лихоманки і є тепер. Мають бути нові логістичні відкриття, які свого часу зробив О. М. Поль і на які тепер сподіваються мешканці міста - міста, якому ще кілька років тому обіцяли долю Детройта.

Однак О.М. Поль відомий не тільки своїми підприємницькими та логістичними проектами, реалізацією фантастичних викликів, а й тими «божевільними» захопленнями, завдяки яким його пам'ятали навіть за радянських часів - колекцією старовини, що стала основою для відкриття музею, який довгий час носив його ім'я. А ще увагою до освітніх установ, попечителем та благодійником яких він був. Катеринослав часів залізної лихоманки був відомий своїми технічними (так званими реальними) освітніми закладами. Чи зуміє теперішній Дніпро відновити і цей потенціал? А чи можливо, дозволить собі більше - розкіш у вигляді якісної гуманітарної освіти? Очевидно, що дніпровські історики зуміли достойно відповісти на нетипові запити влади, а науково-практичні конференція це підкреслила.

Отримано: 02.12.2020 p. 